\title{
The Impact of Transit Oriented Development Apartment Building to Pedestrian's Level of Service in Pondok Cina Station Using Microscopic Modeling
}

\author{
Randy Asad Pradana, R. Jachrizal Sumabrata \\ University of Indonesia, Civil Engineering Department, 16424 Depok, Indonesia
}

\begin{abstract}
The construction of the TOD apartment at the Pondok Cina Station will have an impact on the level of service at the venue. This has a positive impact because there is an increase in KRL users, but it also has the potential to cause problems due to the increased volume. This study aims to analyze the impact of TOD station Pondok Cina apartment development on station service level in 2022 condition and find the best solution to improve service level. The station model is created using PTV VISWALK 10. Validation testing is needed to determine the model is acceptable or not by comparing the model results and actual conditions in the field. Analysis of service level using HCM as a reference. There are several models performed, such as the condition of existing year 2018, condition year 2022 without apartment, condition 2022 with apartment, and alternative condition. Alternative conditions of total change in Pondok Cina station. After the simulation, see the performance of all models based on service level and travel time. The result show given the influence of the apartment, if nothing is done then the level of service worsens from LOS B to LOS E while travel time increases drastically from 78 seconds to 429 seconds by 2022 .
\end{abstract}

\section{Introduction}

With a city area of Jakarta of $661.52 \mathrm{~km}^{2}$ which is occupied by $10,177,924$ residents (2015 data is taken from Jakarta.bps.go.id) with a population density of $15,366.87$ inhabitants / km2. Construction of houses is also increasingly difficult because land for board needs is increasingly limited, including in the areas of Bogor, Depok, Tangerang and Bekasi. This has led to vertical residential development and a growing area of development in Jabodetabek.

The development of the center of Jakarta as a commercial and residential area and accompanied by developments in Bogor, Depok, Tangerang, and Bekasi as residential areas provide a great influence on the transportation system in Jabodetabek. (According to Kemenhub.go.id) the total 2015 trip in Jabodetabek is 40.5 million / day. From these data, $50 \%$ of the trips came from bodetabek who headed to Jakarta. While $40 \%$ travel in Jakarta. From these data, $15 \%$ comes from public transportation and the majority of public transport users come from KRL.

KRL as one of the most popular modes of transportation by bodetabek residents who want to do work in the Jakarta area. And the Jakarta - Bogor route is the route that carries the most passengers, which is $67.8 \%$. At present, the government is building vertical housing with the concept of Transit Oriented Development (TOD). The TOD concept is a transportation development concept that synergizes with land use to accommodate new growth by strengthening the living environment and expanding options and benefits, through optimizing mass public transport networks, such as buses and trains, making it easier for city residents to travel. This TOD concept is used in the Jabodetabek area. One of them is the construction of apartments in the Pondok Cina area which integrates with the Pondok Cina station. This development is one of the many TOD-based developments such as the Tanjung Barat Station and the Tanah Abang Station.

With the construction of TOD-based apartments, KRL capacity during working hours is getting more crowded. So that residents in the apartment are feared not to use KRL even though they have integrated with KRL.

\section{Objective}

The study aims to analyze the level of service of pedestrian facility at Pondok Cina station currently and in 2022.

\section{Methodology}

Methods At this stage it is used to obtain the data needed for research, namely primary data and secondary data. Primary data is the result of direct observation in the field (counting survey) and assisted with recording devices in certain locations. The survey consists of a traffic counting survey that calculates the number of people entering and 
leaving Pondok Cina station and the next survey is recording the speed of people who are at Pondok Cina station. And also the time needed for pedestrians to use a top-up machine and the machine tap into and out of the station. All three data are needed to run the simulation.

Secondary data comes from relevant agencies, such as the Depok City Transportation Agency for the data needs of the Pondok China Station master plan development data such as the existing station area, the area of the development station, and the site plan. PT KCI to find out the number of KRL users at Pondok Cina station and the growth of KRL users.

Collecting research data in several ways. The first to use this distance measurement tool was used to measure the area of the Pondok Cina station and the length of the Pondok Cina station. Then researchers used video recordings during rush hour. From the observation of the data, data processing needs to be done to obtain the necessary variables, such as pedestrian behavior. Researchers also calculate pedestrians who enter and exit the Pondok Cina station. This study also takes into account gender composition because according to Endang Widjajanti's research, 1996, gender differences affect pedestrian speed.

After that the researchers also measured the specifications of the KRL, such as the size of the door, waiting time, train schedule, the number of doors for each carriage, the number of carriages, and the length of the train platform used.

Then the data is entered into Viswalk, for the existing dimensions of the station carried out in CAD beforehand and then can be exported to Viswalk, after that the researcher enters the value of pedestrian behavior that can be entered into Pedestrian Input. Then enter the public transportation dimensions contained in the PT. after that the simulation is run in two dimensions, because each simulation has different results, so the researcher does several simulations and makes the average of the simulation. After that the researcher conducted validation to find out the similarities between the simulation results and the data that had been reviewed. The results obtained from the simulation are in the form of Level of Service, pedestrian density, pedestrian travel time, and others.

Then the researchers made dimensions of the Pondok Cina station which was added to the TOD apartment and run the simulation and counting obtained from the simulation.

In this research, VISWALK PTV software was used to build a model at Pondok Cina station. The VISWALK model simulation uses partial route, meaning pedestrians choose their own route based on the fastest time to reach its destination and not just one route.

After simulating the conditions in 2018, parameters were obtained in terms of density, pedestrian speed, and travel time. Of the three parameters, validation tests were performed by comparing the results recorded using recording devices and simulations. If the results have not reflected the actual conditions, adjustments to pedestrian speed are made.

Scenario forecast for 2022 is based on the growth factor of commuter line KRL users and the operation of Pondok China TOD apartments. In 2022, it consists of the Do Nothing Without Development scenario, Do Something (apartment) Without Development, Do Something With Development (Pondok Cina station masterplan). Do something is a scenario where there is infrastructure development that adds to pedestrian quantity. Whereas development is a scenario of infrastructure development that adds to the pedestrian power, Based on the scenario of DS (apartment) WOD, apartments in Pondok Cina station are factors that influence traffic volume, so that in this study further analysis was conducted to determine the impact of the apartment. The last scenario is DS (apartment) WD (station development).

\subsection{Simulation}

There are four models in the results, which are:

\subsubsection{Model 1: Present Condition}

This model describes the current condition of Pondok Cina KRL station. The data entered to generate model 1 is taken from the data obtained through observations and surveys. Passenger volume that enters the activity area is used as input data, but the data entered is not shared every 15 minutes. The volume data entered is 2800 people per hour. This is done because the units in the Viswalk application are pedestrians per hour, so the data must be adjusted (Table1-2).

Table 1. Pedestrian Level of Service Present Condition

\begin{tabular}{|c|c|c|}
\hline Area & Density $\left(\mathrm{Ped} / \mathrm{m}^{2}\right)$ & LOS \\
\hline 1 & 13,7 & $\mathrm{~A}$ \\
\hline 2 & 15,8 & $\mathrm{~A}$ \\
\hline 3 & 4,4 & $\mathrm{~B}$ \\
\hline
\end{tabular}

Table 2. Pedestrian Time Travel Present Condition

\begin{tabular}{|c|c|c|c|}
\hline Point & Minimum & Average & Maximum \\
\hline 1 & $14,80 \mathrm{~s}$ & $31,36 \mathrm{~s}$ & $75,24 \mathrm{~s}$ \\
\hline 2 & $9,40 \mathrm{~s}$ & $25,76 \mathrm{~s}$ & $78,30 \mathrm{~s}$ \\
\hline 3 & $8,07 \mathrm{~s}$ & $23,31 \mathrm{~s}$ & $58,72 \mathrm{~s}$ \\
\hline
\end{tabular}

\subsubsection{Model 2: Condition Without Apartment in 2022}

This model is a forecasting model, the data entered into this is the existing data and growth data of KRL passengers per year at Pondok Cina station (Table34). The volume of existing data in 2018 is 2800 , while the growth of KRL passengers per year is $7.3 \%$. From these data, estimates can be made of passengers who will use Pondok Cina station in 2022 with the formula:

$$
\begin{gathered}
V_{r}=V_{e} \cdot(1+x)^{n} \\
V_{r}=2800 \cdot(1+0,073)^{4}
\end{gathered}
$$




\section{$V_{r}=3711$ passenger per hour}

Table 3. Pedestrian Level of Service without Apartment in 2022

\begin{tabular}{|c|c|c|}
\hline Area & Density $\left(\mathrm{Ped} / \mathrm{m}^{2}\right)$ & LOS \\
\hline 1 & 6,6 & $\mathrm{~A}$ \\
\hline 2 & 4,2 & $\mathrm{~B}$ \\
\hline 3 & 2,7 & $\mathrm{C}$ \\
\hline
\end{tabular}

Table 4. Pedestrian Time Travel without Apartment in 2022

\begin{tabular}{|c|c|c|c|}
\hline Point & Minimum & Average & Maximum \\
\hline 1 & $14,80 \mathrm{~s}$ & $39,77 \mathrm{~s}$ & $202,40 \mathrm{~s}$ \\
\hline 2 & $9,40 \mathrm{~s}$ & $34,75 \mathrm{~s}$ & $172,33 \mathrm{~s}$ \\
\hline 3 & $8,07 \mathrm{~s}$ & $32,19 \mathrm{~s}$ & $134,59 \mathrm{~s}$ \\
\hline
\end{tabular}

\subsubsection{Model 3: Condition With Apartment in 2022}

This model is a forecasting model, the data entered into this model is the volume obtained from modeling 2 plus the development of an apartment based on Transit Oriented Development. With these various additions, the Pondok Cina station did not make any changes.

Apartment data are as follows:

Number of towers: 4

Number of units: 1845

With this data, because we are reviewing Pondok Cina on the margonda section station, the tower is only 2 , assuming that all units are occupied by 2 people, then the number of people staying in the two towers is 3690 people, then it is assumed that $70 \%$ of people use The KRL that goes to Jakarta and 30\% departs at 6:15 a.m. 07:15 p.m., so there are 775 additional passengers every hour at that time(Table5-6).

Table 5. Pedestrian Level of Service with Apartment in 2022

\begin{tabular}{|c|c|c|}
\hline Area & Density $\left(\mathrm{Ped} / \mathrm{m}^{2}\right)$ & LOS \\
\hline 1 & 4 & B \\
\hline 2 & 2,4 & C \\
\hline 3 & 1,1 & E \\
\hline
\end{tabular}

Table 6. Pedestrian Time Travel with Apartment in 2022

\begin{tabular}{|c|c|c|c|}
\hline Point & Minimum & Average & Maximum \\
\hline 1 & $14,90 \mathrm{~s}$ & $58,20 \mathrm{~s}$ & $179,16 \mathrm{~s}$ \\
\hline 2 & $12,43 \mathrm{~s}$ & $54,65 \mathrm{~s}$ & $429,33 \mathrm{~s}$ \\
\hline 3 & $9,05 \mathrm{~s}$ & $51,54 \mathrm{~s}$ & $359,85 \mathrm{~s}$ \\
\hline
\end{tabular}

\subsubsection{Model 3: Condition Masterplan 2022}

This model is a forecasting model. The data entered into this model are volume data in 2022, number of passengers from UI, and master plan plans from Pondok
Cina station. There was a significant change from the design of Pondok Cina station, namely all activities such as access to the station, use of top-up machines, and tap gate machines, moved to level 2. So that level 1 was sterile from activities and only to wait for trains. And there is also an escalator to the 3rd floor for apartment residents.

In this modeling, 4 towers were included so that there were 1550 additional passengers due to the apartment at $06.15-07.15$. Because the area of the new activity area is quite large, so the researchers designed that the refill machine and tap gate machine be added to prevent stacking and long queues as in previous models.

Because it does not get a plan from the contractor concerned, it is assumed that the master plan is done. The assumption area of the masterplan is 180 meters long and 40 meters wide, so it has an activity area of $7200 \mathrm{~m}^{2}$. This is far greater than the existing condition which has an activity area of $122.76 \mathrm{~m} 2$ (Table7-8).

Table 7. Pedestrian Level of Service Masterplan Condition 2022

\begin{tabular}{|c|c|c|}
\hline Area & Density $\left(\mathrm{Ped} / \mathrm{m}^{2}\right)$ & LOS \\
\hline 1 & 34,83 & A \\
\hline 2 & 6,98 & A \\
\hline 3 & 5,78 & A \\
\hline
\end{tabular}

Table 8. Pedestrian Time Travel Masterplan Condition 2022

\begin{tabular}{|c|c|c|c|}
\hline Point & Minimum & Average & Maximum \\
\hline 1 & $57,17 \mathrm{~s}$ & $81,97 \mathrm{~s}$ & $106 \mathrm{~s}$ \\
\hline 2 & $46,48 \mathrm{~s}$ & $64,17 \mathrm{~s}$ & $83,36 \mathrm{~s}$ \\
\hline 3 & $44,1 \mathrm{~s}$ & $80,9 \mathrm{~s}$ & $148,4 \mathrm{~s}$ \\
\hline
\end{tabular}

\section{Result}

After getting done with data retrieval and survey, the data that has been obtained and the model that has been designed is processed and brought out the result.

\subsection{Comparison}

After running 4 modeling simulations, the results will be compared. Model 1 is an existing condition. Model 2 is a condition in 2022 with no changes in infrastructure and apartments. Model 3 is a condition in 2022 with no infrastructure changes but there are apartments. Model 4 is a condition in 2022 with changes in the infrastructure of Pondok Cina station and the addition of apartments.

It can be said that the existing condition is still quite good, areas 1 and 2 have LOS A while area 3 has LOS B. but if you look at the next 4 years (2022) there will be an increase in KRL users. This can be seen in the number 2 modeling, where area 2 which was LOS A, changed to LOS B, while area 3 which was originally LOS B, changed to LOS C. And this did not include the addition of residents from the Pondok Cina TOD station apartment. 
If we enter the occupants, the number 3 model applies, the situation in 2022 with an additional apartment. Area 1 changes to LOS B which was originally LOS A. Area 2 changes to LOS C and area 3 becomes LOS E. If you see this situation, if no changes are made then the following year, the level of service at Pondok Cina station will get worse. Therefore it is necessary to renovate the station to overcome the KRL users which are increasing every year(Table9).

Table 9. Level of Service Comparison between All Models

\begin{tabular}{|c|c|c|c|}
\hline \multirow{2}{*}{ Model } & \multicolumn{3}{|c|}{ Area } \\
\cline { 2 - 4 } & 1 & 2 & 3 \\
\hline 1 & A & A & B \\
\hline 2 & A & B & C \\
\hline 3 & B & C & E \\
\hline 4 & A & A & A \\
\hline
\end{tabular}

Model number 4 is a condition where the Pondok Cina station is totally changed, so it cannot be compared with the previous 3 models. The Pondok Cina station plans to have a larger station area, the area for top-up machines is wider so that more machines can be installed, and more tap-gate than before. when simulating, the three areas have LOS A(Table10).

Table 10. Pedestrian Time Travel Comparison between All Models

\begin{tabular}{|c|c|c|c|}
\hline & \multicolumn{3}{|c|}{ Time (s) } \\
\hline Model & Minimum & Average & Maximum \\
\hline 1 & 8,07 & 25,76 & 78,3 \\
\hline 2 & 8,76 & 34,75 & 202,4 \\
\hline 3 & 9,05 & 54,65 & 429,3 \\
\hline 4 & 32,4 & 58,8 & 148,4 \\
\hline
\end{tabular}

From the table above, the existing condition which is the number 1 modeling is still quite good, the shortest travel time is 8 seconds which is the state of KRL users going straight to tap gate when entering the station activity area. The longest time is taken for 78 seconds, this happens because KRL users must queue first to refill the card. If we look at the conditions in 2022 that is number 2 model, the shortest travel time is not much different from the number 1 model, but the longest travel time has a rather significant increase, which is 202 seconds. And if we add apartment residents (3 modeling conditions) then the shortest travel time is 9 seconds, but the longest travel time has a very significant increase, which is 429 seconds. This is due to the condition in which the top-up machine only operated 4 pieces and it was difficult to add the engine due to insufficient land and also compounded by the addition of KRL users in 2022.

Because modeling number 4 is a change of station, the time frame is also different from the previous model. the shortest travel time is 32 seconds. This is due to the station activity area going to the tap gate even further, so that the travel time has increased. While the longest travel time is 148 seconds (Figure 1).

Here is a graph of travel time comparison:

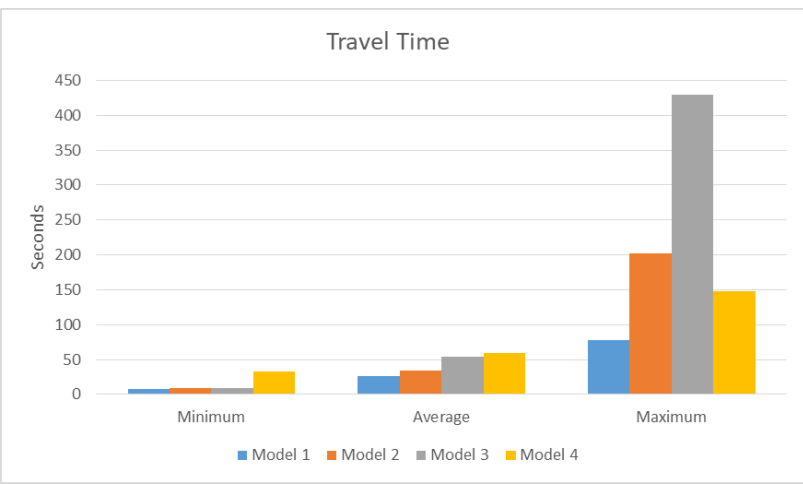

Fig. 1. Pedestrian Time Travel Comparison in Graph

\section{Conclusion}

Through the research results obtained, then the conclusions can be drawn from this research are:

(1) The service level of Pondok Cina station in 2018 from the simulation results is LOS A for the entire area and refill area, while the tap gate area is LOS B.

(2) The level of service of Pondok Cina station in 2022 without apartments from the simulation results is LOS A for the entire area, LOS B for the refill area, and the tap gate area is LOS C.

(3) The level of service at Pondok Cina station in 2022 with the apartment from the simulation results is LOS B for the whole area, LOS C for the refill area, and the tap gate area is LOS E.

(4) The level of service of Pondok Cina station in 2022 with changes in stations from the simulation results is LOS A for the whole area, refill area, and tap gate area.

The recommendation that can be given to the condition of Pondok Cina station are:

(1) It is necessary to enlarge the activity area at Pondok Cina station.

(2) It is necessary to add to the top-up machine to reduce travel time.

\section{Acknowledgements}

The authors are grateful to DPRM Universitas Indonesia for the financial support through PITTA 2018 grants and Mr. Jachrizal Sumabrata who had guided the author in completing this research.

\section{References}

1. Abdullah, J., \& Mazlan, M. H. (2016). Procedia Social and Behavioral Sciences. Characteristics of and Quality of Life in a Transit Oriented Development (TOD) of Bandar Sri Permaisuri, Kuala Lumpur, 1-2. 
2. Ahna, Y., Kowada, T., Tsukaguchi, H., \& Vandebona, p. (2016). Transportation Research Procedia. Estimation of Passenger Flow for Planning and Management of Railway Stations , 1-17.

3. Alexandersson, S., \& Johansson, E. (2013). Pedestrians in microscopic traffic simulation. Gothenburg: Chalmers University of Technology.

4. DCP, N. (2006). Pedestrian Level of Service Study. New York City: Transportation Division.

5. Dridi, M. H. (2015). Scientific Research Publishing. Simulation of High Density Pedestrian Flow: A Microscopic Model , 1-15.

6. Kurniawan, I. (2004). Karakteristik Arus Pejalan Kaki pada Koridor Pejalan Kaki Bawah Tanah Terminal Transit Blok-M Mall. Jakarta: Universitas Indonesia.

7. Kurugod, T. P., Kadam, R. L., \& vinayaka, B. (2017). International Research Journal of Engineering and Technology . Study of Pedestrian Level of Service by Micro-Simulation Using Vissim, 1-13.
8. Malin, L., \& Sandra, S. (2014). Microscopic Simulation of Pedestrian Traffic in a Station Environment: A Study of Actual and Desired Walking Speeds. Norrköping: Linköping University.

9. Martén, J. B., \& Henningsson, J. (2014). Verification and Validation of Viswalk for Building Evacuation Modelling . Lund: Brandteknik, Lunds tekniska högskola, Lunds universitet.

10. Patra, M., Sala, E., \& Ravishankar, K. (2016). Transportation Research Procedia . Evaluation of pedestrian flow characteristics across different facilities inside a railway station, 1-8.

11. Sohoni, A. V. (2016). Transport Research Procedia. Application of the concept of transit oriented development to a suburban neighborhood, 2-3.

12. TD, P., \& P.K.Sarkar. (2016). Procedia Computer Science. Pedestrian Warrants For Developing Countries By Simulation Approach , 1-5.

13. Vision, P. (2011). VISSIM 5.30-05 User Manual. Karlsruhe : Planung Transport Verkehr AG. 